\title{
Capitalism the Inhumane Form: A Lukacsian Comparative Reading of Capitalism in The Mill on the Floss and Ulysses
}

\author{
Ehsan Emami \\ English Department, Neyshabur University, Neyshabur, Iran \\ Email: faridfarhadin@gmail.com
}

\begin{abstract}
For Marxists, capitalism is a real kick in the teeth. Capitalism, as Marxists affirm, is an inhumane, devastating form, because it is antithetical to Marxism, and because it encourages dishonest competition and the destruction of the small by the big. For much worse, it debases culture and transforms all things, even human beings into commodities. Generally most Marxists almost unanimously make this point that capitalism causes negative effects and they are still trying to show them. In this paper Capitalism and some of its effects on the societies depicted in The Mill and Ulysses will be assessed. The reader will learn that the rise of different classes in a capitalist society, according to Lukacs, is the result of the injustice; that these classes struggle and as a result, some of them will disappear along with their culture and civilization; that the capitalist system is barbaric because it turns human beings into animals, love into mere sexual desire; that capitalism has a bad influence on literature and turns it into a commodity; that economic necessity in a capitalist society determines everything.
\end{abstract}

Index Terms - capitalist society, class conflicts, division of labour, Lukacs, Marxism, modernist novel, realistic novel

\section{INTRODUCTION}

One of the defects that Marxists point out to and firmly believe in it, is the 'inhumane' form of capitalism, which is the subject of discussion in this paper. They say that capitalism is brutal and subversive. But to perceive the genesis of this alleged atrocity, it will do the reader good to know the meaning of some key terms explicated by Karl Marx himself: division of labour, contradiction, alienation, property, and class.

As Harrison- Barbet (2001) says, in a capitalist society as the population and naturally productivity and needs augment, the division of labour becomes more distinct and intricate. The contradiction according to Selden (1993) "is expressed in the conflict of interest between capitalist and worker," because the means of production belong to capitalists and labourers who own their tools, at last have nothing to sell save their labour (p. 77). Property and class come from the concept of division of labour. "Property arises from the unequal distribution of labour . . " and this in its turn gives way to the emergence of different classes. Alienation is the corollary of class conflict (Harrison - Barbet, 2001, pp. 264 - 65). Marxists emphasize upon alienation, which as a matter of fact, is the essence of brutality in a capitalist society. Hans Bertens (2001) puts it in this way:

Capitalism, Marxism tells us, thrives on exploiting its labourers... capitalists grow rich... because the labourers that work for them and actually produce goods... get less... Labourers have known this for a long time... What they do not know, however, is how capitalism alienates them from themselves by seeing them in terms of production... as objects rather than human beings (p. 83).

Some crucial elements have to be discussed at length in order to highlight the cruelty of capitalism as much as possible.

\section{Class StrugGle}

As mentioned above, it is the division of labour that gives way to the rise of classes in a capitalist society. It implies that by no means can a capitalist society be a classless society. That is why the Russian democratic- revolutionary critics whom Lukacs (1964) puts on a pedestal, "center their investigations around the power of a writer to create types" (p. 115). They remind us that if characters like Hamlet, Don Quixote and Faust are still alive, and if the greatest values of the past have remained so far, it is because of the creation of such immortal and comprehensive types. Realists as these critics put forward should circumvent the position of mere isolated observers only through a clear understanding of the struggle of classes (Lukacs, 1964).

Lukacs (1964) contends that membership in a class is just about considered as "a biological... unchangeable, necessity, a fate" that must be acquiesced (p. 208). He continues:

The division between the personal individual and the class individual, the accidental nature of conditions of life for the individual, appears only with the emergence of class, which is itself a product of the bourgeoisie. This accidental character is only engendered and developed by competition and the struggle of individuals among themselves. Thus, in 
imagination, individuals seem more free under the dominance of the bourgeoisie than before, because their conditions of life seem accidental, in reality, of course, they are less free, because they are more subjected to the objective compulsion. (p. 208)

Like Lukacs, Brecht also does count class struggle for much: "Problems of society have become problems of humanity, subsuming the inner conflicts and contradictions of the warring parties" (Mulhern, 1992, p. 238). Both The Mill and Ulysses depict bourgeois societies, which in a Marxist view have to contain classes and the writer should clearly show the conflict between them. Now it is better to compare these two novels in this case.

In The Mill George Eliot has created various types- hence class conflicts. A critic has referred to Eliot's dexterity in producing various classes giving Maggie's aunts as an example:

These sisters have married three men dissimilar enough in taste and temper to have each an individual and distinct existence, and yet with a general resemblance in the cast and level of their minds which stamps them as belonging to the same class and the same generations. There is nothing in which George Eliot succeeds more conspicuously than in this very nice art of making her characters like real people, and yet shading them off into the large group which she is describing. (Carroll, 1971, pp. 115-16)

This novel comprises a three- dimensional conflict between two different classes. The conflict happens to be between Mr. Tulliver (a landowner), Lawyer Wakem (a bourgeois), and aunt Glegg (another bourgeois). Of course there are other characters (uncle Glegg, uncle Deane) who can be classed as bourgeois but they are not directly embroiled in the conflict.

Someone called Pivart plans to divert the river from its natural channel, which will have dire results for Mr. Tulliver's family. Mr. Tulliver who emphasizes that "Dorlcote Mill's been in our family a hundred years and better, and nobody ever heard of a Pivart meddling with the river...", and knows "who's at the bottom of it; he's got Wakem to back him and egg him on", despite his wife and especially his sister's opposition who brilliantly says: "This Mr. Pivart's a rich man, by what I can make out, and the rich mostly get things their own way", he goes to the law and loses it (Eliot, 1985, pp.144-45). As a result he must transfer the land and the mill to Wakem. On the other hand a discussion occurs between Mr. Tulliver and aunt Glegg who is a usurer and has made a loan to Mr. Tulliver. She is dead set against Mr.Tulliver's decision on Tom's expensive education. She frets Tulliver family's prodigality will lead to bankruptcy and therefore her money will be in jeopardy. Mrs. Glegg's expression "There is folks I've lent money to, as perhaps I shall repent o' lending money to kin", implies that Mr. Tulliver should get her money back (Eliot, 1985, p. 68). Mr. Tullliver who is headstrong, rash, irritable, prejudiced, incompetent, proud, vindictive and inflexible makes up his mind that he should immediately pay her money back but of course he cannot afford this loan, Tom's expensive education, good money he has spent on law, and naturally Mrs. Glegg's prognostication comes true.

The bourgeois hostility towards landowners is obviously shown in this novel. For instance Mrs. Glegg who is a usurer skins other people by means of her loans and does the same thing with Mr. Tulliver and should be considered as one of the most crucial elements which conduce to Mr. Tulliver's ruin that in its turn symbolizes the extermination of landowners. Also, the reader can find an implicit relation between landowners and peasants. The reader realizes that Mr. Tulliver himself has made a loan to Mr. Moss, his brother in law, who is a poor peasant. Although despite his bankruptcy, Mr. Tulliver decides not to recall the loan from him, the reader deduces from this fact that Mr. Tulliver at least for a certain time has been exploiting Mr. Moss and may say 'tit for tat'. This symbolizes the oppression of the peasants by landowners.

In Ulysses, Joyce describes the capitalist Ireland of the twentieth century. Although it cannot be a classless society, the depiction of classes in Ulysses is not as distinct as it is in The Mill. This is one of the most important faults that Lukacs (1964) finds with modernist writers such as Joyce. He asserts that when writers condone the creation of types in their works they fail to crystallize the influence of social and economic forces in them and naturally their works lack the requisite objectivity. As a matter of fact Ulysses is not so classless as Lukacs thinks. Although vaguely, Jennifer Levine remarks the same thing in his essay on Ulysses. Speaking about 'Aeolus' in which several people meet and talk to each other in The Freeman Newspaper Office, he says: "No coincidence, perhaps, that the little drama being played out between J.J. O'Molloy and his fellow Dubliners repeats the larger drama of social mobility, of class and money..."(Attridge, 1999, p. 146). At a glance the reader can at least clarify some loose classes. For instance she may class Myles Crawford, the editor, and Councilor Nannetti, the business manager for the Freeman's Journal, as the bourgeois and Bloom who works in the journal, as a working class man. Also, s/he should not forget the Dedalus family or Father Cowley as the poor and poverty-stricken.

Of course in a Marxist view the working classes are those who are remunerated for industrial work and usually exploited by the bourgeois. In comparison, Bloom is paid for work in a Journal and is egregiously oppressed by the bourgeois (Nanmetti and Crawford). Bloom wants to print an advertisement for the firm of Alexander Keyes but both the editor and the Counciller repeatedly put a spoke in his wheel because to them the exchange is a minor contretemps, but for Bloom the Keyes advertisement is his major commercial transaction of the day and a 'key' for him as the name Keyes suggests. When Bloom speaks to Nannetti about the ad, Nannetti reacts indifferently and inattentively. In addition, when he telephones the office to talk to Crawford about it, the editor tells professor MacHugh who happens to answer the phone, "tell him go to hell" (Joyce, 1961, p. 137). In another moment when Bloom is at the office and is informing Crawford of the conditions that Keyes has made for the publication of the advertisement, he curtly says: "He can kiss my royal Irish arse, ... anytime he likes, tell him" (Joyce, 1961, p. 147). And leaves the office without telling Bloom what to do. As a rule, 
in Lukacs's view these would not really be objective conflicts because Bloom is always passive. Simultaneously the reader should not be oblivious of this fact that Joyce has peopled his novel with ordinary non-hero characters and his world is a far cry from Eliot's.

\section{Destruction of Culture AND Civilization}

According to Lukacs (1964), 'destruction of culture and civilization' is one of the wickedest atrocities that capitalism commits. He says: "This vision of an imminent cataclysm, of the imminent destruction of culture and of the world, is the idealistically inflated form which a presentiment of class extinction always takes" (p. 39). It means that destruction of culture and civilization happens when a class dominates the other. Both in The Mill and Ulysses the writers show this fact. The only nuance is that this destruction in The Mill transpires in a process which can be seen clearly from the beginning to the end whereas in Ulysses it is implied in some episodes which its distinction needs careful scrutiny.

In 'Telemachus', the first chapter of Ulysses, three characters are introduced to the reader: Stephen Dedalus (one of the main protagonists in the novel), Buck Mulligan (a medical student), and Haines (an English man from Oxford who studies Gaelic language in Dublin). They live on the stairhead of the Martello tower rented by Stephen. Haines as an English man symbolizes English capitalism that has been imposed on Ireland. Joyce uses this character to ironically crystallize how the British have destroyed the Irish culture. In the morning of the day June 16, 1904 in which Ulysses is narrated, an old Irish milk woman brings milk to the Martello Tower for Stephan and his friends. Haines speaks Gaelic to her but she does not understand: "Is it French you are talking, sir? The old woman said to Haines" (Joyce, 1961, p. 14). When she is told that it is Irish, the milk woman is stupefied and asks whether Haines is from west. Buck Mulligan ironically notifies her: "he is English, ... and he thinks we ought to speak Irish in Ireland" (Joyce, 1961, p. 14). Joyce implies that even an old woman that belongs to previous generation does not know Gaelic language let alone the Irish youth such as Stephan. It was for the same reason that Joyce rejected the claims of an Irish cultural nationalism. The young Joyce found the latter -especially the recovery of the Gaelic language, occultism, and folklore-parochial and backward-looking... Joyce supplemented his studies with visits to the Capel Street Library in Dublin, whose new books introduced him to the brilliant Continental literature then published abroad. This reading provided an alternative to the imperialistic inflections of the English poetic tradition as Joyce would later represent it in Ulysses. (Norris, 1998, p. 4)

To extricate Ireland from the tyranny of the English culture, Joyce looked down on Irish culture as the vanquished and instead looked up to the Continent as the source of power and inspiration. It is mostly pertinent that Haines suffers from a kind of hysterical nightmare in which he sees a black panther. This black panther symbolizes destruction as Buck Mulligan later in Ulysses thinks about Haines: “Ah! Destruction! The Black Panther” (Joyce, 1961, p. 412)! In this way Joyce shows that the English capitalism has subverted the Irish language and culture. In addition, Stephan calls himself "a server of a servant", which spells out his relationship to Ireland, a country that is itself a servant to two foreign tyrants: England and Rome (Joyce, 1961, p. 11). To England, the dominant culture, because Ireland is a British colony and to Rome because Ireland's main religion is Catholicism.

In The Mill the reader witnesses a process which highlights the destruction of landowners by the bourgeoisie. A class dominates another as Lukacs contends. Mr Tulliver's demise symbolizes the annihilation of landowners. But for this, the writer does not solely blame the bourgeois group. She excoriates landowners too for their passivity, prejudice, incompetence, inflexibility and corruption which all embody in Mr. Tulliver's character. For example she depicts Mr. Tulliver as a usurer making a loan to and exploiting his poor brother in law. When landowners aimed only at maintaining their land and the current situation, the bourgeois planned to obtain everything. The landowners' strategy was to defend whereas the bourgeois strategy was to attack.

When Mr. Tulliver is on his deathbed he expresses a wish to Tom: "you'll try and get the old mill back" (Eliot, 1985, p. 326). Although Tom succeeds to get it back, by no stretch of the imagination can the reader say that it means the landowners will resuscitate because Tom has already changed into a bourgeois since he started working at the trading firm, Guest and Co. It was the firm, which bought Dorlcote Mill and appointed Tom as manager.

Also, George Eliot organizes a mordant stricture on the government of that time for its cooperation with the bourgeois which by itself typifies how far the bourgeois had influenced upon and taken control of the government. As a matter of fact, and as Lukacs (1964) says, "the bourgeois and the government are one and the same" (p. 32). In The Mill the reader observes the people's deep mistrust of the English law system. Although Wakem is a rascal, as Mr. Tulliver says, and after the exchange between Mrs. Tulliver and Wakem, the narrator's comment confirms Mr. Tulliver's assessment of Wakem's character, the bourgeois bureaucratic government after squandering Mr. Tulliver's good money announces Wakem as the winner. Then by the death of Mr. Tulliver at the end of the novel, Eliot implies the destruction of a culture, which belongs to landowners. Additionally, as it is clear she does not fail to elucidate the role of government in it.

\section{BARBARISM OF THE CAPIT ALIST SYSTEM}

'Barbarism of the capitalist system', as Lukacs (1964) says is the corollary of the capitalist division of labour which "permeates all human relationships, it becomes the way of life, the decisive determinant of thoughts and emotions"; and causes human beings to be "transformed into parts of an inhuman machine" (p. 163). In his The Meaning of Contemporary Realism Lukacs (1979) contends: "The opposition of man as animal to man as social being leads straight to a glorification 
of the abnormal and to an undisguised anti-humanism" (p. 32). Of course here he refers to those modern philosophers (such as Heidegger) who condoned the social aspect of human beings. Lukacs (1979) even transcends this and mentions that the conditions that capitalism brings about turn man into a beast.

\section{A. Animality}

Both in Ulysses and The Mill, capitalism has changed some characters into human- like animals. Buck Mulligan, Haines, and Blazes Boylan in Ulysses, lawyer Wakem, aunt Glegg in The Mill may be included.

In Ulysses, Mulligan takes Stephen's money without any feeling of guilt. He is even going to make Stephen borrow money from Haines. Stephen has rented the Tower and the other two live in it like parasites. In 'Telemachus' Stephen submits the key to the tower to Mulligan and because these two scuffle in the 'Oxen of the Sun', Stephen realizes that it is impossible to return to the tower and sees Mulligan as a 'usurper'. Mulligan always tortures Stephan by reminding him of his poor mother whose request (when she was on his deathbed) that he pray for her like a Christian, was refused by Stephen. One day Stephen goes to Mulligan's house. His mother asks him who is in his room and Mulligan cruelly answers: "O, it's only Dedalus whose mother is beastly dead" (Joyce, 1961, p. 8) Also, Haines symbolizes English capitalism and Stephen is now both symbolically and literally homeless. He has been victimized by the tyrant Mulligan, just as his country has been spiritually 'usurped' and plundered by England (Haines).

In 'Crice' Joyce (1961) reiterates symbolically the brutality of English capitalism imposed on Ireland. In the brothel district Stephen states "But in here it is I must kill the priest and the king" (p. 589). Private Carr thinks that Stephan is menacing King Edward VII and attacks on him. Actually, Stephen is repeating the adage that Ireland is the captive of the double tyrants of the Roman Catholic Church and Britain. More symbolism is also apparent in Carr's attack on Stephen. The blow represents, symbolically, English oppression of a nearly defenseless Ireland.

Blazes Boylan treats Bloom brutally. Just like Mulligan and Haines, he is a usurper too. While Mulligan and Haines have usurped Stephen's house, as Goldman (1966) says, Boylan has warped Bloom's life by usurping his wife, Molly. Throughout the novel the reader sees Bloom think of Molly and Boylan that is one of the most salient themes of the novel.

In The Mill after Mr. Tulliver's bankruptcy, Mrs. Tulliver decides to "avert the result most to be dreaded, and prevent Wakem from entertaining the purpose of bidding for the mill" (Eliot, 1985, p. 225). Therefore, she goes to Wakem and modestly entreats him not to buy the mill, instead let Guest and Co buy it and put Mr. Tulliver as the manager. As a matter of fact, by this suggestion Mr. Tulliver goes out of the frying pan into the fire because it makes Wakem think up a wicked scheme. The following paragraph mentioned by the narrator (whom the reader may identify with Eliot herself) conspicuously shows Wakem's animality:

Wakem was not without this parenthetic vindictiveness towards the uncomplimentary miller; and now Mrs. Tulliver had put the notion into his head, it presented itself to him as a pleasure to do the very thing that would cause Mr. Tulliver the most deadly mortification... not made up of crude malice, but mingling with it the relish of self-approbation. To see an enemy humiliated gives a certain contentment, but this is jejune compared with... seeing him humiliated by your benevolent action or concession on his behalf. That is a sort of revenge which falls into the scale of virtue... and here was an opportunity of... making him his own servant. (Eliot, 1985, pp. 231-2)

When Mr. Tulliver is ill and on bed, the aunts and uncles gather together in his house as Mrs. Clegg puts it "to advise and consult about what's to be done in this disgrace as has fallen upon the family..." (Eliot, 1985, p. 190). Of course the sisters bicker and criticize and reveal only their triviality and selfish materialism. Eventually Tom who is present, musters all his courage and proposes that if they think it is a disgrace and their things must be sold up, they had better prevent it by letting them use the money which aunt Glegg and aunt Pullet think of leaving to him and Maggie. He is even ready to work in order to pay his aunts' money's interest, and in this way reveals his manliness. At this moment, aunt Glegg again shows her brutality and bourgeois essence by the rejection of Tom's Suggestion. Even in this tough situation she cannot bring herself to dispense with her interest and money as a usurer:

And my money... it's to go and be sunk in other folk's furniture, and encourage 'em in luxury and extravagance as they've no means of supporting... and my money's to go and be squandered on them as have had the same chance as me, only they've been wicked and wasteful... that isn't my sperrit. (Eliot, 1985, p. 196)

In George Eliot The Critical Heritage, David Carroll (1971) brings an unknown critic in who puts emphasis on the animality embedded in Maggie's aunts: "The Dodson family are stingy, selfish wretches, who give no sympathy and require none, who would let a neighbour starve, and let a brother be bankrupt when a very little assistance would save him from the disgrace..." p. 133). As it is clear, aunt Glegg does not have mercy on her own sister and nieces whose life is about to be destroyed let alone others.

\section{B. Love}

Capitalism even brutalizes feelings including Love. In The Historical Novel, Lukacs (1989) has discussed this matter as such: "This brutalization of feeling manifests itself in literature to an ever increasing extent, most clearly of all in the description and portrayal of love, where the physical-sexual side gains growing ascendancy over the passion itself' (p. 194).

The best example can be given from Ulysses. Before going to Bloom's house in order to have sex with Molly, Blazes Boylan who is buying a present of fruit, wine, and perfume for her, refers to her as an invalid: "send it at once, will you? He said. It's for an invalid" (Joyce, 1961, p. 226). Also, he flirts with the clerk arrogantly: "Blazes Boylan looked into the 
cut of her blouse. A young pullet" (Joyce, 1961, p. 228). Boylan all the time is obsessed with physical sexuality.

The affair between Molly and Boylan is one of the most crucial themes in the novel and Bloom is always obsessed with it. Throughout the novel the reader will understand that neither of them thinks highly of one another. Boylan thinks of sexual pleasure aggressively all the time and Molly has set her heart on Boylan's money. Once Bloom remembers what Molly told him after having a dance with Boylan: "Is that boylan well off? He has money. Why? I noticed he had a good smell off his breath dancing" (Joyce, 1961, p. 69). According to Boylan's characteristics implied by the writer, Joyce makes it clear that Boylan is a mere stud; he reduces everything to sex, and to him women are less than human.

There is a passionate love story in The Mill too. At first Maggie makes a mistake and declares her love for Philip but the narrator's implication that "It was one of those dangerous moments when speech is at once sincere and deceptive..." (Eliot, 1985, p. 306), elucidates that in fact, Maggie does not love but pities him. This fact then, switches Maggie's love to Stephen Guest. Of course this time it is a true love.

Stephen Guest compared to Blazes Boylan who stridently looks down on women, is unfaithful and dishonest. Although he criticizes Maggie to Lucy, the reader is cognizant that he is attracted to her. As a matter of fact, he tries to dupe Lucy and distract her attention from the developing love between him and Maggie. He is completely oblivious of morality. He proposes that they elope to Scotland. That is why when the narrator affirms that despite Philip's accusation, Stephen is not a hypocrite but experiencing a moral conflict, the reader impugns her. Even if the reader considers the narrator's comment true, s/he cannot condone his lack of morality and responsibility towards the others. K. M. Newton (1991) comments that Maggie has to be blamed too, because "by revealing her love-history with Philip, Maggie unwittingly tempts Lucy to see nothing of significance in the strange vibrations between Maggie and Stephen” (p. 73). But as the reader shall see Maggie at least possesses the temerity to compensate and take the responsibility for the consequences.

Unlike Stephan, Maggie complies with the standards of morality conspicuously. Maggie resists all Stephen's entreaties to marry him: "I must not, cannot seek my own happiness by sacrificing others" (Eliot, 1985, p. 409). One day when they are left alone, Stephen grasps the opportunity and urges Maggie to go rowing. They go a long way past the meeting point with Lucy and during their journey Stephen incessantly eggs Maggie on that they elope to Scotland. At first Maggie capitulates to Stephen but eventually after spending a night with Stephen on a Dutch steamer which is supposed to take them to Mudport, Maggie makes up her mind firmly that she should return to St Ogg's. In fact, her decision is a courageous self-punishing, because "she had brought sorrow into the lives of others-into the lives that were knit up with hers by trust and love" (Eliot, 1985, p. 429). Therefore, courageously she returns to St Ogg's and not only is treated cruelly by the people but is also disowned by her brother, Tom. Dorothea Barrett (1991) mentions some reasons for Maggie's return to St Ogg's. On the one hand she quotes Pauline Nestor's remark that George Eliot has embedded her own belief-that women in general suffer from the vulnerability that results from their greater capacity for love-in Maggie. Nestor says that this idea comes from the fact that women's sexual need is also the means of their oppression. Therefore to remove male domination from without they must first overcome the domination of sexual craving from within. That is, to enjoy freedom one should extricate her/himself from the desire for it and as Nestor reiterates, this is exactly what Maggie does. On the other hand Barrett (1991) quoting the narrator that "She had made up her mind to suffer" (Eliot 1985: 432), contends that Maggie's decision is not only a victory of self-assertion over male domination but also an act of masochistic self-repression (pp. 68-9).

It is obvious that Maggie's renunciation and swimming-against-the-current cause her not to be affected by repercussions of capitalism. In comparison, Stephen Guest and especially Blazes Boylan (both are bourgeois) do not or cannot resist this bad effect of capitalism. But it should be noted that by no means is Stephen like Boylan. Stephen loves Maggie but he is unfaithful and at the same time brutal towards Lucy and Philip. Both Maggie and Stephen agree that their love is natural, but unlike Stephen, Maggie sees also that faithfulness, pity and memory are natural too, and that loyal ties with others are at the heart of moral goodness and duty. On the contrary Blazes Boylan is depicted in Ulysses as a sheer animal. It seems that love is against the grain of him. The concept of love in which Boylan seems to believe is the same as the physical pleasure against which Lukacs in his The Historical Novel and T.S. Eliot as one of the greatest critics of the twentieth century, in his The Waste Land protest.

\section{The Two Nations}

The phrase 'the two nations' is not a new term. Benjamin Disraeli proposed it for the first time in the nineteenth century. For his novel Sybil (1845) Disraeli chose a suitable subtitle, The Two Nations dividing the England of the rich from the other nation, the England of the poor. Lukacs (1964) also believes that a true realist must depict "the inexorable division between the two nations", because it is not but the atrocious capitalism- and its division of labour- which makes a deep cleavage between the rich and the poor in the society (p. 147).

In Ulysses, Leopold Bloom is the most sympathetic character. Although thinking all the time of Boylan whose breath, as Molly says, implies that he is a man of means, Bloom is not inattentive to the other nation, the Ireland of the poor. Being a realist, Joyce (1961), through the meanderings of Bloom in Dublin, put these two nations before the reader's very eyes. In the 'Lestrygonians' Bloom who wanders through the center of Dublin spies Dedalus's daughter Dilly: "Good Lord, the poor child's dress is in flitters. Underfed she looks too" (p. 152). On the other hand in the newspaper office he sees Brayden the owner of the twin newspaper who is a bourgeois rich man and reveals his affluence in this way: "Welts of flesh behind him. Fat folds of neck, fat, neck, fat, neck" (p. 117). Somewhere else he notices two poor children: "By Brady's cottages a boy for the skins lolled, his bucket of offal linked, smoking a chewed fagbutt. A smaller girl with scars 
of eczema on her forehead eyed him..." (p. 71). Also, Joyce (1961) organizes a few moving scenes in order to display the financial predicament of the poor Dedalus family: Maggie Dedalus's telling her hungry sisters that the pawn shop would not accept Stephen's books as well as her dishing out pea soup begged from a nun, and the drunken Simon trying to convince Dilly that he has no money to give her to buy some food for the family.

In The Mill the reader on the one hand witnesses lawyer Wakem, Stephen Guest, the Gleggs, and the Deanes as the England of the rich, and on the other hand the Moss Family as the England of the poor. Note how Mrs. Moss answers Mr. Glegg who tells her they should raise the money that they owe to Mr. Tulliver:

O sir, you don't know what bad luck my husband's had with his stock. The farm's suffering so as never was for want o'stock; and we've sold all the wheat, and we're behind with our rent... and I'd sit up and work half the night... but there's them poor children... four of 'em such little uns.... (Eliot, 1985, p. 198).

\section{The CAPITALIZATION OF LiteratURE}

Capitalism transforms literature into a commodity that can be bought and sold. It includes as Lukacs (1964) says, "the writer's ideas, emotions and convictions to the paper on which he writes them down..." (p. 49). To crystallize this matter, Lukacs (1964) mentions Lost Illusions, an exemplary novel by Balzac, whose theme is the transformation of literature into a commodity. In this novel "the writers and journalists are exploited, their talent has become a commodity, an object of profiteering by the capitalist speculators who deal in literature" (pp. 49-50). Cliff Slaughter (1980) speaks about Baudelaire's similar ideas. He struggled passionately, as Slaughter says, to create against the conditions that the bourgeois had made. According to Baudelaire, the bourgeois society can make a writer, even at the height of his creativity, "a whore" (p. 189). Lukacs (1964) too, uses the term "prostitution of literature" (p. 51). Although the theme of neither of the novels, The Mill and Ulysses, has been mainly devoted to prostitution of literature, there are especially in Ulysses some implied streaks by which the writers highlight this subject.

Teaching in a class, Stephen makes a pun on a pier, that it is a "disappointed bridge" (Joyce, 1961, p. 25). Simultaneously thinking of Haines, he envisages that if he repeats it to Haines, he will simply place it among his collection of Stephen's bright sayings; once again Stephen will be labeled as merely a jester at the court of the English tyrant. Haines, a capitalist, who does not understand literature and Stephen as a poet, tries to exploit them for his own advantage. That is to say, he deteriorates literature into a laughing matter and the poet into a jester. Even if a loose symbol, at least it shows the writer's remonstrance with the English capitalism (Haines) that detracts from the value of the Irish literature and culture.

Lukacs (1964) quotes an interesting paragraph from Balzac's Lost Illusions in which an experienced journalist advises a tyro:

a fashionable author is haughtier and harsher towards the new generation than the most leech-like of publishers. Where the publisher sees only a loss of money, the fashionable author fears a rival: the publisher merely rejects the beginner, the fashionable author annihilates him. (p. 50)

This is what exactly happens in Ulysses. In chapter nine Stephen accompanies five principals in Dublin's National Library. The principals discuss an assembly of the Dublin literary intelligentsia at the domicile of the novelist George Moore. Although Mulligan has been invited by Moore and asked to bring Haines with him, Stephen has not been. It is not accidental that Joyce (1971) bitterly lampoons Moore in his Pomes Peny-each:

O lovely land where the shamrock grows!

(Allow me, ladies, to blow my nose)

And a play on the World and Holy Paul

And some woman's legs that I can't recall

Written by Moore, a genuine gent

That lives on his property's ten per cent. (p. 43)

Also, the men mention: "Mr. Russell, rumour has it, is gathering together a sheaf of our younger poets' verses. We are all looking forward anxiously" (Joyce, 1961, p. 192). To this collection too, Stephen has not been suggested to contribute. Obviously the circumspect reader will realize that both the novelist George Moore and the editor George Russell whose newspaper Stephen (perhaps for the same reason) refers to as “The Pig's Paper”, eye him as a rival (Joyce, 1961, p. 193). As a result, Stephen being a dangerous rival has to be eliminated.

George Eliot (1985) in her novel consciously or unconsciously remonstrates with that time's ruling ideology of literature. The bourgeois who controlled the market determined this ideology. The market-led economy obliged writers to write novels with endings in which as Maggie says "the blond-haired women carry away all the happiness" (Eliot, 1985, p 302). These novels were thought to be attractive to buyers and as a rule highly marketable. Somewhere in (book Fifth) The Mill Maggie discusses a novel, Corinne to whom Philip has lent. To criticize this novel and actually the dominant literary ideology, the writer puts these fantastic words into her heroine's mouth:

'I didn't finish the book,' said Maggie. I shut it up, and determined to read no further. I foresaw that that light-complexioned girl would win away all the love from Corinne and make her miserable. I'm determined to read no more books where the blond haired women carry away all the happiness. I should begin to have a prejudice against them. If you could give me some story, now, where the dark woman triumphs, it would restore the balance. (p. 302) 
But it is amazing to see that Eliot herself has capitulated to this ideology and organized her novel in such a way that her 'dark unhappy' heroine should die at the end. Perhaps it was for her capitulation to the public taste that as Pinion (1989) says many people including Princess Louise visited and extolled her.

This subject might be discussed biographically. Joyce's biography elucidates that as opposed to Eliot, he was neither praised nor encouraged by anyone. Especially publishers bullied him inordinately, merely because he was an unconventional writer and did not comply with the interests of the market. "Already he was showing a determination to face the facts of life,... and without the least regard for conventional ideas of ethics or for susceptibilities, or the slightest consideration for public taste"(Duff, 1932, p. 31). Joyce's letters to various publishers divulge the difficult labours it was necessary for him to undertake when he wanted to publish something. In a letter to a publisher (Mr. Cerf who eventually agreed to publish Ulysses) Joyce (1961) poignantly complains: "Publishers and printers alike seemed to agree among themselves... not to publish anything of mine as I wrote it" (p. xiii).

One publisher, Grant Richards despite signing a contract to publish Dubliners, importuned Joyce for many changes and did not take the responsibility. But when The Egoist started publishing it successfully, Richards made certain of its reception and at last acquiesced in its publication (Norris, 1998). Some other publishers in Dublin who had made a contract to publish Dubliners broke it and burned the galleys of it. Outraged, Joyce (1971) published a famous sarcastic poem, 'Gas from a Burner', to take revenge:

This lovely land that always sent

Her writers and artists to banishment

And in spirit of Irish fun

Betrayed her own leaders, one by one. (p. 42)

In brief, it was Joyce who "showed the novelists how they failed as creative artists by giving the public what it wanted" (Duff, 1932, p. 32).

It was only Ezra Pound, the eminent poet and Joyce's friend, who abetted him to publish his works because perhaps he had realized the brutalization of literature by capitalism. A critic has pointed it out in this way: "Pound understood the difficulty of financing modernistic writing whose formal traits- simple, direct language enriched by resonant international erudition and cultural allusion- made it difficult to market to a general public" (Norris, 1998, p. 10).

Eliot also did not trust publishers and critics. Living in a patriarchal society whose literary ideology was specified by men she feared to divulge her real name and sex, lest they might deteriorate her works. Then a pen-name was necessary to shield her against biased criticism resulting from her irregular social status. As F.B. Pinion (1989) reports, a certain Mr. Liggins announces himself as the writer of Adam Bede and The Scenes and it "led to Marian's intervention, and the identity of George Eliot... had to be made public in the summer of 1859" (p. 29). Perhaps if this had not ensued she would never have revealed her identity.

\section{CONCLUSION}

Although in this paper Marxism has been introduced as the opponent of capitalism, it is not its only enemy. Many people living in capitalist societies have lost faith in capitalism. Especially in Western developed countries, governments have realized that they should seek new economic theories. For example, when a depression period takes place, they might not comply with the capitalists' belief that government should keep out of economic affairs. The recent recession which made Obama administration introduce tougher measures to Wall Street testifies the fact. However, Marxism is a complex theory and there are lots of Marxist critics who hold different views, but in case of capitalism, almost all of them unanimously believe that capitalism is not a good theory and vitiates society. The only difference is that some of them including Lukacs consider capitalism as completely negative. For Lukacs "capitalism always represents above all a reign of 'reification', of fragmentation of humanity..." (Slaughter, 1980, p. 141). Simultaneously some including Fredric Jameson disapprove of capitalism in part. For Jameson "Capitalism destroys genuine human relationships, but also for the first time liberates human kind from village idiocy and the tyranny and intolerance of tribal life" (Mulhern, 1992, p. 176). As it was shown, all the above-mentioned elements put forward by Lukacs-class struggle, destruction of culture and civilization, barbarism of the capitalist system, the capitalization of literature, and economic necessity-exist in both novels. Although some of these elements such as destruction of culture and civilization have been even more beautifully depicted in Ulysses and the circumspect reader will confirm it, Lukacs would probably not endorse them because firstly, Joyce has expressed them in so an indirect way that the reader needs intellectuality and careful scrutiny to perceive them and secondly, in Ulysses subjectivity through the use of stream of consciousness has been foregrounded to both of which Lukacs is dead set against. Lukacs would confirm The Mill because of its direct, clear-cut, and traditional use of these elements. On the contrary, he would not acquiesce in the depiction of these elements in Ulysses because as opposed to Eliot, Joyce's method is indirect and vague, because Joyce looks more at the world inside or characters' minds rather than at the world outside. That every work of art should be written after the fashion of the $19^{\text {th }}$ century novelists might be regarded as Lukacs's insensibility to the role of variety in literature.

\section{REFERENCES}

[1] Attridge, D. (ed.) (1999). The Cambridge Companion to James Joyce. Cambridge: Cambridge University Press. 
[2] Barrett, D. (1991). Vocation And Desire George Eliot's Heroines. London: Routledge.

[3] Bertens, H. (2001). Literary Theory The Basics. London: Routledge.

[4] Bressler, C. E. (1994). Literary Criticism An Introduction to Theory and Practice. New Jersey: Prentice Hall.

[5] Carroll, D. (ed.) (1971). George Eliot The Critical Heritage. London: Routledge and Kegan Paul.

[6] Duff, C. (1932). James Joyce And The Plain Reader. London: Desmond Harmsworth.

[7] Eliot, G. (1985). The Mill On The Floss. London: Macmillan.

[8] Goldman, A. (1966). The Joyce Paradox. London: Routledge and Kegan Paul.

[9] Harrison- Barbet, A. (ed.) (2001). Mastering Philosophy. New York: Palgrave.

[10] Joyce, J. (1961). Ulysses. New York: Random.

[11] Joyce, J. (1971) Pomes Penyeach and other verses. London: Faber And Faber.

[12] Lukacs, G. (1989). The Historical Novel. Translated by H. \& S. Mitchell. London: Merlin Press.

[13] Lukacs, G. (1971). The Theory of the Novel. Translated by Anna Bastock. Cambridge: The Mit Press.

[14] Lukacs, G. (1964). Studies In European Realism. New York: Grosset and Dunlap.

[15] Lukacs, G. (1979). The Meaning Of Contemporary Realism. Translated by J. \& N. Mander. London: Merlin Press.

[16] Mulhern, F. (ed.) (1992). Contemporary Marxist Literary Criticism. London: Longman.

[17] Newton, K. M. (ed.) (1991). George Eliot. London: Longman

[18] Norris, M. (ed.) (1998). A Companion to James Joyce's Ulysses. Boston: Bedford.

[19] Pinion, F. B. (1989). A George Eliot Companion. London: Macmillan.

[20] Selden, R. \& P. Widdowson. (ed.) (1993). A Reader's Guide to Contemporary Literary Theory. Harvester Wheatsheaf.

[21] Slaughter, C. (1980). Marxism, Ideology and Literature. London: Macmillan.

Ehsan Emami He is forty years old. He studied English Literature at Shahid Beheshti University, Tehran-Iran. He has been teaching English Literature since 2004. His field of study in literary criticism is Marxism and in literature, Twentieth cent ury fiction. He is now a lecturer in English Literature and the Head of the English Department at Neyshabur University-Iran. 